\title{
PENGGUNAAN METODE ANALYTIC HIERARCHY PROCESS DALAM PENGAMBILAN KEPUTUSAN PENENTUAN PRIORITAS PROGRAM KERJA DOMPET DHUAFA YOGYAKARTA
}

\author{
Djoko Wijono ${ }^{1)}$ \\ Idham Ibty ${ }^{2}$ \\ ${ }^{1)}$ Fakultas Ekonomi, Universitas Proklamasi 45 Yogyakarta \\ e-mail:dj.wijono@gmail.com \\ ${ }^{2)}$ Fakultas Isispol, Universitas Proklamasi 45 Yogyakarta \\ e-mail: idham.ibty@gmail.com
}

\begin{abstract}
Manager always faced to make a choice from various alternatives. Here the necessary prioritization and test the consistency of the choices that have been made. In complex situations, decision-making is not influenced by one factor alone but is multifactorial and includes various levels and interests. The analytic hierarchy process (AHP) is a structured technique for organizing and analyzing complex decisions, based on mathematics and psychology. It was developed by Thomas L. Saaty in the 1970s and has been extensively studied and refined since then. The AHP helps decision makers find one that best suits their goal and their understanding of the problem. It provides a comprehensive and rational framework for structuring a decision problem, for representing and quantifying its elements, for relating those elements to overall goals, and for evaluating alternative solutions. In this study, AHP used for decission making in Dhompet Dhuafa planning programs. First we decompose their decision problem into a hierarchy of more easily comprehended sub-problems, The elements of the hierarchy can relate to any aspect of the decision problem. The AHP converts these evaluations to numerical values that can be processed and compared over the entire range of the problem. This study use metodhologies: brain storming discuss, indepth interview, and collect secondary data. Find Dhompet Dhuafa solution problems by AHP.The good point of this study is showed how to use AHP for decision making.
\end{abstract}

Keywords: analytical hierrchy process (AHP), keputusan, program kerja

\section{PENDAHULUAN}

Pengambilan keputusan oleh para manajer seringkali dihadapkan pada permasalahan yang sulit karena beragamnya kriteria pengambilan keputusan, bobot pertimbangan, sehingga memakan waktu yang lama. Berbagai metode dipergunakan, diantaranya adalah Analytical Hierarchy Process (AHP). AHP merupakan suatu metode pengambilan keputusan yang dikembangkan oleh Thomas L. Saaty. Model pendukung keputusan ini menguraikan masalah multi kriteria atau multi faktor yang kompleks menjadi suatu hirarki. Hirarki didefinisikan sebagai suatu representasi dari sebuah permasalahan yang kompleks dalam suatu struktur multi level dimana level pertama adalah tujuan, yang diikuti level kriteria, sub kriteria, dan seterusnya ke bawah hingga level terakhir dari alternatif. AHP memberikan nilai bobot relatif dari suatu kriteria majemuk atau alternatif majemuk secara intuitif, yaitu dengan melakukan perbandingan berpasangan dengan menggunakan skala perbandingan berpasangan yang ditentukan oleh Saaty. Analitycal Hierarchy Process (AHP) juga menguji konsistensi penilaian. Konsistensi yang diharapkan adalah yang mendekati sempurna agar menghasilkan keputusan yang valid. Ratio konsistensi yang diharapkan adalah kurang dari atau sama dengan $10 \%$. 
Dompet Dhuafa Yogyakarta merupakan lembaga amil zakat yang mempunyai berbagai macam program untuk penyaluran dana zakat, sodakoh, infaq dari muzaki. Dana yang terkumpul semakin lama semakin banyak, dan konsep utama merek menyalurkan dana secara produktif. Tidak hanya mengentaskan kemiskinan, namun juga harus mengena pada sasaran yang tepat, dan terjadi peningkatan pendidikan, dan perbaikan kualitas hidup. Sasaran penyaluran dana juga luas, meliputi seluruh Daerah Istimewa Yogyakarta, pada berbagai macam segmen. Di antara berbagai program, Dompet Dhuafa menggulirkan program Ekonomi Produktif SAKOFA. Tujuannya untuk mengembangkan usaha mikro yang sudah dimiliki keluarga dhuafa agar bisa lebih maju dan dapat menjadikan mustahik menjadi munfiq (orang yang mampu bersedekah) karena usahanya berkembang lebih baik.

Bentuk Program Ekonomi Produktif SAKOFA adalah berupa pendampingan sebagai inkubasi usaha dan penguatan kapabilitas usaha dengan pemberian tambahan modal. Peserta program akan menerima bantuan modal dengan syarat dan ketentuan pengguliran yang telah ditentukan. Keterbatasan sumberdaya menuntut ketepatan pengambilan keputusan penentuan prioritas lokasi pelaksanaan program ekonomi produktif. Pemilihan lokasi pelaksanaan program ekonomi produktif berdasarkan kriteria daerah yang banyak memiliki masyarakat dhuafa, memiliki kegiatan produktif, punya motivasi untuk berkembang, bersedia dibina, dan berada dalam satu lokasi.

Analytical Hierrchy Process (AHP) dapat membantu pengambilan keputusan penentuan prioritas lokasi program kerja Dompet Dhuafa Yogyakarta. Metode AHP ini membantu memecahkan persoalan yang kompleks dengan menstruktur dan meranking prioritas hirarki kriteria dari berbagai alternatif dalam pemecahan suatu masalah.

\section{KAJIAN TEORI}

\section{Konsep Pengambilan Keputusan}

Pengambilan keputusan merupakan hal yang pokok bagi manajer, karena keputusan merupakan rangkaian tindakan yang perlu diikuti dalam memecahkan masalah untuk menghindari atau mengurangi dampak negatif atau untuk memanfaatkan kesempatan di dalam perusahaan. Ada empat tahapan dalam pengambilan keputusan (Laudon, 2006) yaitu:

1. Kegiatan Inteligen yaitu proses pencarian informasi dan data dari lingkungan yang berguna bagi pemecahan masalah.

2. Kegiatan Merancang yaitu menemukan, mengembangkan, dan menganalisa arah tindakan yang mungkin dapat dipergunakan. Dalam hal ini mengandung prosesproses untuk memahami masalah, untuk menghasilkan cara pemecahan masalah dan untuk menguji apakah cara pemecahan tersebut dapat dilaksanakan.

3. Kegiatan Memilih yaitu memilih arah tindakan tertentu dari semua arah tindakan yang ada. Pilihan ditentukan dan dilaksanakan.

4. Kegiatan Menelaah disebut juga pemahaman yaitu menyelidiki lingkungan tentang kondisi-kondisi yang memerlukan keputusan. Data mentah yang diperoleh diolah dan diperiksa untuk dijadikan petunjuk yang dapat menentukan masalahnya.

Dengan adanya sistem pendukung keputusan (decission support system), kualitas keputusan yang dihasilkan semakin berkualitas. Model sistem yang dipergunakan untuk mengambil keputusan dapat bersifat tertutup atau terbuka. Model sistem pengambilan keputusan yang tertutup menganggap bahwa orang yang rasional secara logis menguji 
semua alternatif, membuat urutan berdasarkan hasilnya yang lebih disukai, dan memilih alternatif yang mendatangkan hasil terbaik. Sedangkan pada sistem pengambilan keputusan yang terbuka, pengambil keputusan dianggap tidak harus logis dan sepenuhnya rasional, tetapi lebih banyak menunjukkan rasionalitas hanya dalam batas-batas yang ditentukan oleh latar belakang, penglihatan alternatif-alternatif, dan kemampuan untuk menangani model keputusan.

\section{Pengertian Analytical Hierarchy Process}

Metoda Analytical Hierrchy Process (AHP) dikembangkan oleh Prof. Thomas Lorie Saaty dari Wharton Business School di awal tahun 1970, yang digunakan untuk mencari rangking atau urutan prioritas dari berbagai alternatif dalam pemecahan suatu permasalahan. Dalam kehidupan sehari-hari, seseorang senantiasa dihadapkan untuk melakukan pilihan dari berbagai alternatif. Di sini diperlukan penentuan prioritas dan uji konsistensi terhadap pilihan-pilihan yang telah dilakukan. Dalam situasi yang kompleks, pengambilan keputusan tidak dipengaruhi oleh satu faktor saja melainkan multifaktor dan mencakup berbagai jenjang maupun kepentingan.

Metode AHP ini membantu memecahkan persoalan yang kompleks dengan menstruktur suatu hirarki kriteria, pihak yang berkepentingan, dan hasil dengan menarik berbagai pertimbangan guna mengembangkan bobot atau prioritas. Metode ini juga menggabungkan kekuatan dari perasaan dan logika yang bersangkutan pada berbagai persoalan, lalu mensintesis berbagai pertimbangan yang beragam menjadi hasil yang cocok dengan perkiraan kita secara intuitif sebagaimana yang dipresentasikan pada pertimbangan yang telah dibuat. Selain itu AHP juga memiliki perhatian khusus tentang penyimpangan dari konsistensi, pengukuran dan ketergantungan di dalam dan di luar kelompok elemen strukturnya.

Penelitian sebelumnya oleh Zainal Arifin (2010) mengenai penerapan Metode Analytical Hierarchy Process (AHP) untuk menentukan sisa hasil usaha pada Koperasi Pegawai Negeri. Metode AHP banyak diterapkan pada kasus-kasus tertentu yang membutuhkan penunjang keputusan serta pengambilan keputusan, sehingga metode ini menjadi relevan untuk penelitian yang lain yang berhubungan dengan sistem penunjang keputusan sesuai dengan kebutuhan.

\section{Prinsip-Prinsip Dasar Analytic Hierarchy Process}

Dalam menyelesaikan persoalan dengan AHP ada beberapa prinsip yang harus dipahami diantaranya adalah: decomposition, comparative judgment, synthesis of priority, dan logical consistency.

Decomposition (Penyusunan Hirarki). Pengertian decomposition adalah memecahkan atau membagi problema yang utuh menjadi unsur-unsurnya ke bentuk hirarki proses pengambilan keputusan, dimana setiap unsur atau elemen saling berhubungan. Untuk mendapatkan hasil yang akurat, pemecahan dilakukan terhadap unsur-unsur sampai tidak mungkin dilakukan pemecahan lebih lanjut, sehingga didapatkan beberapa tingkatan dari persoalan yang hendak dipecahkan. Bentuk struktur dekomposition yakni:

Tingkat pertama : Tujuan keputusan (Goal)

Tingkata kedua : Kriteria - kriteria

Tingkat ketiga : Alternatif - alternatif 
Goal

Kriteria

Sub Kriteria

Alternatif

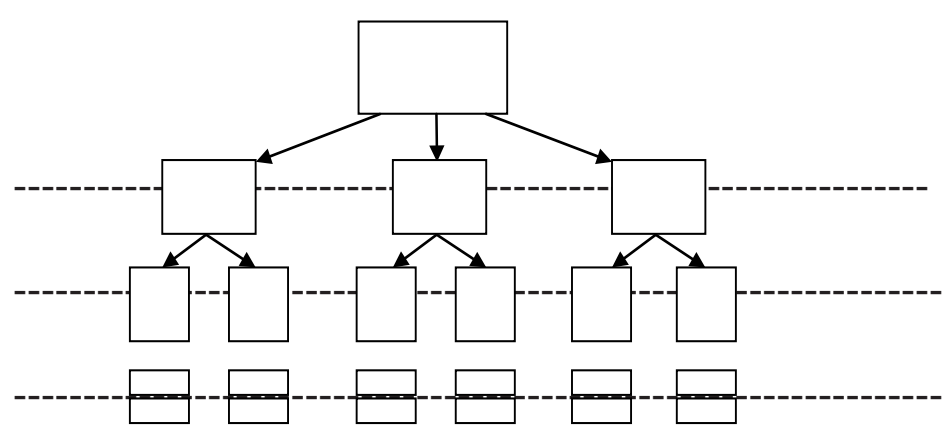

Gambar 1. Struktur Hirarki pada AHP

Hirarki masalah disusun untuk membantu proses pengambilan keputusan dengan memperhatikan seluruh elemen keputusan yang terlibat dalam sistem. Sebagian besar masalah menjadi sulit untuk diselesaikan karena proses pemecahannya dilakukan tanpa memandang masalah sebagai suatu sistem dengan suatu struktur tertentu.

Menurut Saaty (1990), hirarki didefinisikan sebagai suatu representasi dari sebuah permasalahan yang kompleks dalam suatu struktur multi level di mana level pertama adalah tujuan, yang diikuti level faktor, kriteria, sub kriteria, dan seterusnya ke bawah hingga level terakhir dari alternatif. Dengan hirarki, suatu masalah yang kompleks dapat diuraikan ke dalam kelompok-kelompoknya yang kemudian diatur menjadi suatu bentuk hirarki sehingga permasalahan akan tampak lebih terstruktur dan sistematis (Thomas, 2010)

Comparative Judgement (Penilaian Perbandingan Berpasangan). Comparative Judgement dilakukan dengan penilaian tentang kepentingan relatif dua elemen pada suatu tingkat tertentu dalam kaitannya dengan tingkatan di atasnya. Penilaian ini merupakan inti dari AHP karena akan berpengaruh terhadap urutan prioritas dari elemen-elemennya. Hasil dari penilaian ini lebih mudah disajikan dalam bentuk pairwise comparisons matrix yaitu matriks perbandingan berpasangan memuat tingkat preferensi beberapa alternatif untuk tiap kriteria. Nilai numerik yang dikenakan untuk seluruh perbandingan diperoleh dari skala perbandingan 1 sampai 9 yang telah ditetapkan oleh Saaty (1990), seperti pada tabel berikut ini.

Most

Important

Neutral

Most

Elemen A 5.3

Important

Tabel 1. Skala AHP dan Definisinya

\begin{tabular}{cl}
\hline Skala & Definisi dari "Importance" \\
\hline 1 & Sama pentingnya (equal Importance) \\
3 & Sedikit lebih penting (slightly more importance) \\
5 & Jelas lebih penting (materially more importance) \\
7 & Sangat jelas penting (significantly more importance) \\
9 & Mutlak lebih penting (absolutely more importance) \\
\hline
\end{tabular}

Sumber : Saaty, TL The Analitycal Hierarchy Process: Planning, Priority Setting, Resource Allocation 
Skala preferensi yang digunakan yaitu skala 1 yang menunjukkan tingkat yang paling rendah (equal importance) sampai dengan skala 9 yang menunjukkan tingkatan yang paling tinggi (extreme importance). Selain nilai-nilai di atas, nilainilai antaranya juga bisa digunakan, yakni 2, 4, 6, dan 8 . Nilai-nilai ini menggambarkan hubungan kepentingan di antara nilai-nilai ganjil yang disebutkan di atas. Sementara jika kepentingannya terbalik, maka kita dapat menggunakan angka resiprokal dari nilai-nilai di atas.

Dalam membuat matriks berpasangan, kita hanya perlu menentukan matriks segitiga atas saja karena matriks segitiga bawah hanyalah nilai resiprokal dari matriks segitiga atas. Selain itu, nilai-nilai diagonal pada matriks perbandingan berpasangan adalah satu (karena setiap item dibandingkan dengan dirinya sendiri). Dengan demikian, apabila kita ingin membuat matriks perbandingan berpasangan dengan jumlah $n$ item, maka kita hanya perlu membuat perbandingan sejumlah $n(n-1) / 2$.

Pertanyaan yang biasa diajukan dalam penyusunan skala kepentingan adalah:

1. Elemen mana yang lebih (penting/disuka/...) ?

2. Berapa kali lebih (penting/disuka ...)?

Agar diperoleh skala yang bermanfaat ketika membandingkan dua elemen seseorang yang akan memberikan jawaban perlu pengertian menyeluruh tentang elemen - elemen yang dibandingkan dan relevansinya terhadap kriteria atau tujuan yang dipelajari.

Synthesis of priority (Sintesa Prioritas). Synthesis of priority dilakukan dengan menggunakan eigen vector method untuk mendapatkan bobot relatif bagi unsur unsur pengambilan keputusan. Prosesnya dilakukan dengan mengalikan prioritas lokal dengan prioritas dari kriteria bersangkutan di level atasnya dan menambahkannya ke tiap elemen dalam level yang dipengaruhi kriteria. Hasilnya berupa prioritas global yang kemudian digunakan untuk memberikan bobot pada prioritas lokal dari elemen di level terendah sesuai dengan kriterianya

Logical Consistency. Logical Consistency merupakan karakteristik penting AHP. Hal ini dicapai dengan mengagresikan seluruh eigen vector yang diperoleh dari berbagai tingkatan hirarki dan selanjutnya diperoleh suatu vektor composite tertimbang yang menghasilkan urutan pengambilan keputusan.

\section{METODE PENELITIAN}

\section{Metode Analisis Kualitatif}

Metode analisis kualitatif adalah dengan melakukan wawancara secara mendalam kepada para manajer Dompet Dhuafa Yogyakarta untuk menggali kriteria-kriteria dan alternatif-alternatif penentuan lokasi pelaksanaan program kerja ekonomi produktif SAKOFA serta diskusi tentang prosedur penentuan lokasi program kerja. Berdasarkan hasil wawancara dan diskusi, pengambilan keputusan pemilihan lokasi pelaksanaan program ekonomi produktif SAKOFA sebagai berikut:

1. Manajemen menerima masukan awal baik dari Dompet Dhuafa pusat, jejaring, donatur, dan pihak-pihak lain termasuk proposal dari masyarakat yang masuk.

2. Melakukan penelitian dengan survei secara random anggota masyarakat di lokasi tersebut berdasarkan kesesuaian antara karakteristik calon peserta program dengan kriteria program SAKOFA. 
Kriteria penerima/peserta program ekonomi produktif SAKOFA yaitu:

1. Dhuafa, rata-rata pendapatan dibawah UMR

2. Mempunyai usaha/kegiatan produktif (usaha mikro)

3. Memiliki motivasi untuk berkembang

4. Bersedia dibina (mengikuti program pelatihan manajemen usaha).

5. Berada dalam satu lokasi/kawasan (dalam satu desa / dusun)

\section{Metode Analisis Kuantitatif}

Untuk analisis kuantitatif dalam studi kasus ini akan digunakan metode Analytical Hierarchy Process (AHP) dalam pengambilan keputusan penentuan prioritas lokasi program kerja. Dalam kasus ini, metode AHP akan membantu memproses tiap usulan atau alternatif lokasi program kerja sehingga pengambil keputusan bisa mengambil keputusan dengan tepat. Langkah dan prosedur penggunaan metode AHP sebagai berikut:

1. Mendefinisikan masalah dan menentukan solusi yang diinginkan.

2. Membuat struktur hirarki yang diawali dengan tujuan umum, dilanjutkan dengan kriteria-kriteria dan alternaif-alternatif pilihan yang ingin di ranking.

3. Membentuk matriks perbandingan berpasangan (pairwise comparison) yang menggambarkan kontribusi relatif atau pengaruh setiap elemen terhadap masingmasing tujuan atau kriteria yang setingkat diatasnya. Perbandingan dilakukan berdasarkan pilihan atau judgement dari pembuat keputusan dengan menilai tingkat tingkat kepentingan suatu elemen dibandingkan elemen lainnya.

4. Menormalkan data yaitu dengan membagi nilai dari setiap elemen di dalam matriks yang berpasangan dengan nilai total dari setiap kolom.

5. Menghitung nilai eigen vector dan menguji konsistensinya, jika tidak konsisten maka pengambilan data (preferensi) perlu diulangi. Nilai eigen vector yang dimaksud adalah nilai eigen vector maksimum yang diperoleh dengan manual.

6. Mengulangi langkah 3, 4, dan 5 untuk seluruh tingkat hirarki.

7. Menghitung eigen vector dari setiap matriks perbandingan berpasangan. Nilai eigen vector merupakan bobot setiap elemen. Langkah ini untuk mensintesis pilihan dalam penentuan prioritas elemen-elemen pada tingkat hirarki terendah sampai pencapaian tujuan.

8. Menguji konsistensi hirarki. Jika tidak memenuhi dengan $\mathrm{CR}<0,10$; maka penilaian harus diulang kembali.

\section{HASIL DAN PEMBAHASAN}

Berdasarkan kriteria dan alternatif-alternatif lokasi penerima program ekonomi produktif SAKOFA yang sudah ditetapkan manajemen Dompet Dhuafa Yogyakarta, maka pengambilan keputusan dengan menggunakan Metode Analytical Hierarchy Process (AHP) prosesnya sebagai berikut:

1. Menetapkan permasalahan, kriteria, dan alternatif pilihan.

2. Membentuk matrik pairwise comparison kriteria.

3. Menentukan rangking kriteria dalam bentuk vector prioritas (disebut juga eigen vector ternormalisasi).

4. Menentukan rangking kriteria dalam bentuk vector prioritas (disebut juga eigen vector ternormalisasi).

5. Menentukan ranking dari alternatif lokasi dengan cara menghitung eigen vector untuk tiap kirteria. 


\section{Menetapkan Permasalahan, Kriteria, dan Alternatif Pilihan}

Langkah-langkah dalam proses menetapkan permasalahan, kriteria, dan alternatif pilihan adalah:

1. Permasalahan: Menentukan pilihan lokasi pelaksanaan program SAKOFA yang tepat.

2. Kriteria lokasi terbaik yang dipilih yaitu masyarakatnya sebagai calon penerima/ peserta program ekonomi produktif SAKOFA harus memenuhi kriteria:

Kriteria A: Dhuafa, dilihat rata-rata penghasilannya masih di bawah UMR.

Kriteria B: Mempunyai usaha/kegiatan produktif (usaha mikro).

Kriteria C: Memiliki motivasi untuk berkembang.

Kriteria D: Bersedia dibina (mengikuti program pelatihan manajemen usaha).

Kriteria E: Berada dalam satu lokasi/kawasan.

Catatan: Jumlah kriteria atau sub kriteria, minimal 3. Karena jika hanya dua maka akan berpengaruh terhadap nilai CR (lihat tabel daftar rasio indeks konsistensi/RI)

\section{Membentuk Matrik Pairwise Comparison Kriteria}

Terlebih dahulu melakukan penilaian perbandingan berpasangan antar kriteria. Perbandingan antar kriteria didasarkan pada kebijakan yang sudah ditetapkan oleh pihak manajemen. Keputusan hasil perbandingan berpasangan antarkriteria sebagai berikut:

Kriteria A adalah 5 kali lebih penting dari Kriteria E.

Kriteria A adalah 4 kali lebih penting dari Kriteria D.

Kriteria A adalah 3 kali lebih penting dari Kriteria C.

Kriteria A adalah 2 kali lebih penting dari Kriteria B.

Kriteria B adalah 4 kali lebih penting dari Kriteria E.

Kriteria B adalah 3 kali lebih penting dari Kriteria D.

Kriteria B adalah 2 kali lebih penting dari Kriteria C

Kriteria $\mathrm{C}$ adalah 3 kali lebih penting dari Kriteria E.

Kriteria $\mathrm{C}$ adalah 1 kali lebih penting dari Kriteria D.

Kriteria D adalah 2 kali lebih penting dari Kriteria E.

Catatan: karena ada 5 kriteria maka terdapat 10 kali perbandingan (dihitung dengan $n(n$ $1) / 2)$.

Hasil perbandingan berpasangan antar kriteria yang disusun dalam bentuk matrik Pairwise Comparison sebagai berikut:

Tabel 2. Pairwise comparation matrix

\begin{tabular}{c|c|c|c|c|c}
\hline \multicolumn{7}{c}{ Pairwise comparation matrix } \\
\hline Kriteria & A & B & C & D & E \\
\hline A & 1 & 2 & 3 & 4 & 5 \\
B & $1 / 2$ & 1 & 2 & 3 & 4 \\
C & $1 / 3$ & $1 / 2$ & 1 & 1 & 3 \\
D & $1 / 4$ & $1 / 3$ & 1 & 1 & 2 \\
E & $1 / 5$ & $1 / 4$ & $1 / 3$ & $1 / 2$ & 1
\end{tabular}




\section{Menentukan Rangking Kriteria dalam Bentuk Vector Prioritas (Eigen Vector Ternormalisasi).}

Langkah-langkah penyusunannya sebagai berikut:

1. Ubah matriks Pairwise Comparison ke bentuk desimal dan jumlahkan tiap kolom tersebut.

2. Hitung Eigen Vector Normalisasi dengan cara: jumlahkan tiap baris kemudian dibagi dengan jumlah kriteria. Jumlah kriteria dalam kasus ini adalah 5.

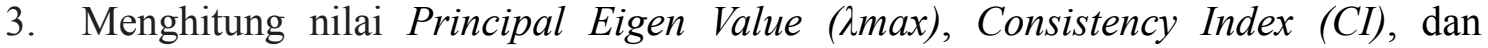
Consistency Ratio (CR) untuk mengetahui apakah penilaian perbandingan kriteria bersifat konsisten.

Tabel 3. Eigen Vector Normalisasi

\begin{tabular}{|c|c|c|c|c|c|c|}
\hline \multicolumn{7}{|c|}{ Pairwise comparation matrix } \\
\hline Kriteria & A & $\mathrm{B}$ & $\mathrm{C}$ & $\mathrm{D}$ & $\mathrm{E}$ & Eigen Vector Normalisasi \\
\hline A & 1,00 & 2,00 & 3,00 & 4,00 & 5,00 & 0,418245799 \\
\hline B & 0,50 & 1,00 & 2,00 & 3,00 & 4,00 & 0,263811895 \\
\hline $\mathrm{C}$ & 0,33 & 0,50 & 1,00 & 1,00 & 3,00 & 0,142012235 \\
\hline $\mathrm{D}$ & 0,25 & 0,33 & 1,00 & 1,00 & 2,00 & 0,113216366 \\
\hline $\mathrm{E}$ & 0,20 & 0,25 & 0,33 & 0,50 & 1,00 & 0,062713704 \\
\hline Jumlah & 2,28 & 4,08 & 7,33 & 9,50 & 15,00 & 1,000000000 \\
\hline \multicolumn{6}{|c|}{ Principal Eigen Value $(\lambda \max )$} & 5,089910582 \\
\hline \multicolumn{6}{|c|}{ Consistency Index (CI) } & 0,022477645 \\
\hline \multicolumn{6}{|c|}{ Consistency Ratio (CR) } & 0,020069326 \\
\hline
\end{tabular}

Keterangan:

- Jumlah merupakan penjumlahan dari semua angka yang ada pada baris diatasnya dalam satu kolom.

- Eigen Vector merupakan hasil penjumlahan dari semua sel disebelah Kirinya (pada baris yang sama) setelah terlebih dahulu dibagi dengan baris jumlah yang ada dibawahnya, kemudian hasil penjumlahan tersebut dibagi dengan angka 5.

Angka 3 diperoleh dari jumlah kriteria yaitu harga, fitur, dan teknologi.

- $\quad$ Eigen vector $=0,418245799$ diperoleh dari perhitungan

$$
(1,00 / 2,28+2,00 / 4,08+3,00 / 7,33+4,00 / 9,50+5,00 / 15,0) * 1 / 5
$$

- $\quad$ Eigen vector $=0,263811895$ diperoleh dari perhitungan

$$
(0,50 / 2,28+1,00 / 4,08+2,00 / 7,33+3,00 / 9,50+4,00 / 15,0) * 1 / 5
$$

$-\mathrm{dst}$

- Eigen Vector menunjukan bobot dari masing-masing kriteria, jadi dalam hal ini Kriteria A (Dhuafa) merupakan bobot tertinggi/terpenting dalam pemilihan lokasi, disusul Kriteria B (Ada kegiatan produktif /usaha mikro).

- Setelah mendapatkan bobot untuk setiap kriteria (yang ada pada kolom Eigen Vector), maka selanjutnya mengecek apakah bobot yang dibuat konsisten atau tidak. Untuk hal ini, yang pertama yang dilakukan adalah menghitung Principal Eigen Value ( $\lambda$ max ) matrix.

- Principal Eigen Value ( $\lambda \max )$ matrix perhitungannya dengan cara menjumlahkan hasil perkalian antara jumlah dan priority vector. 
- $\quad$ Principal Eigen Value $(\lambda \max )=$ $(2,28 \times 0,418245799)+(4,08 \times 0,263811895)+(7,33 \times 0,142012235)+(9,50 \times$ $0,113216366)+(15,0 \times 0,062713704)=5,089910582$

- $\quad$ Menghitung Consistency Index (CI) dengan rumus:

$\mathrm{CI}=(\lambda \max -\mathrm{n}) /(\mathrm{n}-1)$, untuk $\mathrm{n}=5$

$\mathrm{CI}=(5,089910582-5) /(5-1)=0,022477645$, CI mendekati nol berarti pembobotan yang dilakukan konsisten.

- Menghitung Consistency Ratio (CR) diperoleh dengan rumus $\mathrm{CR}=\mathrm{CI} / \mathrm{RI}$, nilai RI (Random Index) bergantung pada jumlah kriteria seperti pada tabel berikut:

\begin{tabular}{cc}
\multicolumn{3}{c}{ Tabel 4. Daftar Random Index $(\mathrm{RI})$} \\
\hline Ukuran Matriks & Nilai RI \\
\hline 1,2 & 0,00 \\
3 & 0,58 \\
4 & 0,90 \\
5 & 1,12 \\
6 & 1,24 \\
7 & 1,32 \\
8 & 1,41 \\
9 & 1,45 \\
10 & 1,49 \\
11 & 1,51 \\
\hline 12 & 1,58 \\
\hline
\end{tabular}

Sumber: (Rochmasari, 2010)

Keterangan: Apabila nilai $\mathrm{CR} \leq 0,10$ maka data konsisten atau dapat ditoleransi tetapi bila $\mathrm{CR} \geq 0,10$ maka data tidak konsisten dan perlu dilakukan revisi. Apabila nilai $\mathrm{CR}=0$, dapat dikatakan "Perfectly Consistent".

Jadi untuk $\mathrm{n}=5$ dan $\mathrm{RI}=1,12$

$\mathrm{CR}=\mathrm{CI} / \mathrm{RI}=0,022477645 / 1,12=0,020069326$

Jika hasil perhitungan CR lebih kecil atau sama dengan 0,10, ketidakkonsistenan masih bisa diterima, sebaliknya jika lebih besar dari 0,10 , tidak bisa diterima.

Menentukan Ranking dari Alternatif Lokasi dengan Cara Menghitung Eigen Vector untuk Tiap Kirteria

1. Memberikan penilaian bobot Kriteria A (Dhuafa) pada alternatif pilihan Lokasi:

Lokasi 1 jumlahnya 4 kali lebih banyak dari Lokasi 2

Lokasi 1 jumlahnya 3 kali lebih banyak dari Lokasi 3

Lokasi 2 jumlahnya 1/2 kali lebih banyak dari Lokasi 3 
Tabel 5. Pairwise comparation matrix Kriteria A (Dhuafa)

\begin{tabular}{|c|c|c|c|c|}
\hline \multicolumn{5}{|c|}{ Pairwise comparation matrix } \\
\hline Kriteria & Lokasi 1 & Lokasi 2 & Lokasi 3 & Eigen Vector Normalisasi \\
\hline Lokasi 1 & 1,00 & 4,00 & 3,00 & 0,6237 \\
\hline Lokasi 2 & 0,25 & 1,00 & 0,50 & 0,1374 \\
\hline Lokasi 3 & 0,33 & 2,00 & 1,00 & 0,2389 \\
\hline Jumlah & 1,58 & 7,00 & 4,50 & 1,0000 \\
\hline \multicolumn{4}{|c|}{ Principal Eigen Value $(\lambda \max )$} & 3,0224 \\
\hline \multicolumn{4}{|c|}{ Consistency Index (CI) } & 0,0112 \\
\hline \multicolumn{4}{|c|}{ Consistency Ratio (CR) } & 0,0193 \\
\hline
\end{tabular}

Arti dari tabel di atas adalah dari ketiga lokasi, yang paling banyak adalah Lokasi 1 dengan skor 0,6237, disusul Lokasi 3 dengan skor 0,2389 dan Lokasi 2 dengan skor 0,1374 .

Nilai CI adalah 0,01 yang berarti pembobotan kurang konsisten, tetapi karena nilai $\mathrm{CR}=0,019$ lebih kecil dari 0,10 maka kekonsistenan penilaian kriteria masih bisa diterima.

2. Memberikan penilaian bobot Kriteria B (ada Kegiatan Produktif/Usaha Mikro) pada alternatif pilihan Lokasi:

Lokasi 1 jumlahnya $1 / 2$ kali lebih banyak dari Lokasi 2

Lokasi 1 jumlahnya 2 kali lebih banyak dari Lokasi 3

Lokasi 2 jumlahnya 3 kali lebih banyak dari Lokasi 3

Tabel 6. Pairwise comparation matrix Kriteria B

\begin{tabular}{|c|c|c|c|c|}
\hline \multicolumn{5}{|c|}{ Pairwise comparation matrix } \\
\hline Kriteria & Lokasi 1 & Lokasi 2 & Lokasi 3 & Eigen Vector Normalisasi \\
\hline Lokasi 1 & 1,00 & 0,50 & 2,00 & 0,2974 \\
\hline Lokasi 2 & 2,00 & 1,00 & 3,00 & 0,5393 \\
\hline Lokasi 3 & 0,50 & 0,33 & 1,00 & 0,1633 \\
\hline Jumlah & 3,50 & 1,83 & 6,00 & 1,0000 \\
\hline \multicolumn{4}{|c|}{ Principal Eigen Value $(\lambda \max )$} & 3,0076 \\
\hline \multicolumn{4}{|c|}{ Consistency Index $(\mathrm{CI})$} & 0,0038 \\
\hline \multicolumn{4}{|c|}{ Consistency Ratio (CR) } & 0,0065 \\
\hline
\end{tabular}

Arti dari tabel di atas adalah dari ketiga lokasi, yang paling banyak adalah Lokasi 2 dengan skor 0,5393, disusul Lokasi 1 dengan skor 0,2974 dan Lokasi 3 dengan skor 0,1633 .

Nilai CI adalah 0,004 yang berarti pembobotan kurang konsisten, tetapi karena nilai $\mathrm{CR}=0,007$ lebih kecil dari 0,10 maka kekonsistenan penilaian kriteria masih bisa diterima. 
3. Memberikan penilaian bobot Kriteria C (Motivasi Berkembang) pada alternatif pilihan Lokasi:

Lokasi 1 jumlahnya 2 kali lebih banyak dari Lokasi 2

Lokasi 1 jumlahnya 1/3 kali lebih banyak dari Lokasi 3

Lokasi 2 jumlahnya 1/3 kali lebih banyak dari Lokasi 3

Tabel 7. Pairwise comparation matrix Kriteria C

\begin{tabular}{|c|c|c|c|c|}
\hline \multicolumn{5}{|c|}{ Pairwise comparation matrix } \\
\hline Kriteria & Lokasi 1 & Lokasi 2 & Lokasi 3 & Eigen Vector Normalisasi \\
\hline Lokasi 1 & 1,00 & 2,00 & 0,33 & 0,2515 \\
\hline Lokasi 2 & 0,50 & 1,00 & 0,33 & 0,1589 \\
\hline Lokasi 3 & 3,00 & 3,00 & 1,00 & 0,5897 \\
\hline Jumlah & 4,50 & 6,00 & 1,66 & 1,0000 \\
\hline \multicolumn{4}{|c|}{ Principal Eigen Value $(\lambda \max )$} & 3,0636 \\
\hline \multicolumn{4}{|c|}{ Consistency Index (CI) } & 0,0318 \\
\hline \multicolumn{4}{|c|}{ Consistency Ratio (CR) } & 0,0548 \\
\hline
\end{tabular}

Arti dari tabel di atas adalah dari ketiga lokasi, yang paling banyak adalah Lokasi 3 dengan skor 0,5897, disusul Lokasi 1 dengan skor 0,2515 dan Lokasi 2 dengan skor 0,1589 .

Nilai CI adalah 0,0318 yang berarti pembobotan kurang konsisten, tetapi karena nilai $\mathrm{CR}=0,0548$ lebih kecil dari 0,10 maka kekonsistenan penilaian kriteria masih bisa diterima.

4. Memberikan penilaian bobot Kriteria D (bersedia dibina) pada alternatif pilihan Lokasi:

Lokasi 1 jumlahnya 3 kali lebih banyak dari Lokasi 2

Lokasi 1 jumlahnya 2 kali lebih banyak dari Lokasi 3

Lokasi 2 jumlahnya 1/2 kali lebih banyak dari Lokasi 3

Tabel 8. Pairwise comparation matrix Kriteria D

\begin{tabular}{ccccc}
\hline \multicolumn{5}{c}{ Pairwise comparation matrix } \\
\hline Kriteria & Lokasi 1 & Lokasi 2 & Lokasi 3 & Eigen Vector Normalisasi \\
\hline Lokasi 1 & 1,00 & 3,00 & 2,00 & 0,5393 \\
\hline Lokasi 2 & 0,33 & 1,00 & 0,50 & 0,1633 \\
\hline Lokasi 3 & 0,50 & 2,00 & 1,00 & 0,2974 \\
\hline Jumlah & 1,83 & 6,00 & 3,50 & 1,0000 \\
\hline \multicolumn{5}{c}{ Principal Eigen Value ( $\lambda$ max) } \\
Consistency Index (CI) & 3,0076 \\
& Consistency Ratio (CR) & 0,0038 \\
\end{tabular}

Arti dari tabel di atas adalah dari ketiga lokasi, yang paling banyak adalah Lokasi 1 dengan skor 0,5393, disusul Lokasi 3 dengan skor 0,2974 dan Lokasi 2 dengan skor 0,1633 . 
Nilai CI adalah 0,0038 yang berarti pembobotan kurang konsisten, tetapi karena nilai $\mathrm{CR}=0,0065$ lebih kecil dari 0,10 maka kekonsistenan penilaian kriteria masih bisa diterima.

5. Memberikan penilaian bobot Kriteria E (berada dalam satu lokasi/berdekatan) pada alternatif pilihan Lokasi

Lokasi 1 jumlahnya 3 kali lebih banyak dari Lokasi 2

Lokasi 1 jumlahnya 2 kali lebih banyak dari Lokasi 3

Lokasi 2 jumlahnya 1/2 kali lebih banyak dari Lokasi 3

Tabel 9. Pairwise comparation matrix Kriteria E

\begin{tabular}{|c|c|c|c|c|}
\hline \multicolumn{5}{|c|}{ Pairwise comparation matrix } \\
\hline Kriteria & Lokasi 1 & Lokasi 2 & Lokasi 3 & Eigen Vector Normalisasi \\
\hline Lokasi 1 & 1,00 & 2,00 & 4,00 & 0,5714 \\
\hline Lokasi 2 & 0,50 & 1,00 & 2,00 & 0,2857 \\
\hline Lokasi 3 & 0,25 & 0,50 & 1,00 & 0,1429 \\
\hline Jumlah & 1,75 & 3,50 & 7,00 & 1,0000 \\
\hline \multicolumn{4}{|c|}{ Principal Eigen Value $(\lambda \max )$} & 3,0000 \\
\hline \multicolumn{4}{|c|}{ Consistency Index (CI) } & 0,0000 \\
\hline \multicolumn{4}{|c|}{ Consistency Ratio (CR) } & 0,0000 \\
\hline
\end{tabular}

Arti dari tabel di atas adalah dari ketiga lokasi, yang paling banyak adalah Lokasi 1 dengan skor 0,5714,disusul Lokasi 2 dengan skor 0,2857 dan Lokasi 3 dengan skor 0,1429 .

Nilai CI adalah 0,0 yang berarti pembobotan konsisten, tetapi karena nilai $\mathrm{CR}=0,0$ berarti penilaian kriteria konsisten.

\section{Menghitung Total Skor Kriteria untuk Ketiga Lokasi}

Semua hasil penilaian bobot kelima kriteria tersebut disusun dalam bentuk tabel yang disebut Overall composite weight.

Tabel 10. Overall composite weight

\begin{tabular}{ccccc}
\hline Overall composite weight & Weight & Lokasi 1 & Lokasi 2 & Lokasi 3 \\
\hline Kriteria A & 0,4182 & 0,6237 & 0,1374 & 0,2389 \\
Kriteria B & 0,2638 & 0,2974 & 0,5393 & 0,1633 \\
Kriteria C & 0,1420 & 0,2515 & 0,1589 & 0,5897 \\
Kriteria D & 0,1132 & 0,5393 & 0,1633 & 0,2974 \\
Kriteria E & 0,0627 & 0,5714 & 0,2857 & 0,1429 \\
\hline Composite Weight & & 0,4719 & 0,2587 & 0,2694 \\
\hline
\end{tabular}

\section{Keterangan:}

- Weight diambil dari kolom Eigen Vector dalam matrix kriteria.

- Kolom (Lokasi 1, Lokasi 2, Lokasi 3) diambil dari kolom Eigen Vector kelima matrix Kriteria A s/d E. 
- Composite weight diperoleh dari hasil jumlah perkalian kolom tiap Lokasi dengan Weight.

Lokasi $1=(0,4182 \times 0,6237)+(0,2638 \times 0,2974)+(0,1420 \times 0,2515)+(0,1132 \times$ $0,5393)+(0,0627 \times 0,5714)=0,4719$

Lokasi $2=(0,4182 \times 0,1374)+(0,2638 \times 0,5393)+(0,1420 \times 0,1589)+(0,1132 \times$ $0,1633)+(0,0627 \times 0,2857)=0,2587$

Lokasi $3=(0,4182 \times 0,2389)+(0,2638 \times 0,1633)+(0,1420 \times 0,5897)+(0,1132 \times$ $0,2974)+(0,0627 \times 0,1429)=0,2694$

Dari tabel diatas dapat disimpulkan bahwa Lokasi 1 mempunyai skor paling tinggi yaitu 0,4719, kemudian Lokasi 3 dengan skor 0,2694 dan paling bawah Lokasi 2 0,2587. Sehingga Lokasi yang paling baik dan dipilih adalah Lokasi 1.

\section{SIMPULAN}

Simpulan yang dapat diambil adalah:

1. Metode Analytical Hierarchy Process (AHP) merupakan salah satu model pengambilan keputusan multikriteria yang dapat membantu kerangka berpikir manusia dimana faktor logika, pengalaman, pengetahuan, dan pendapat dioptimasikan ke dalam suatu proses sistematis.

2. Metode Analytical Hierarchy Process (AHP) dapat membantu pengambil keputusan Dompet Dhuafa Yogyakarta dalam menentukan pemilihan lokasi terbaik untuk pelaksanaan program ekonomi produktif SAKOFA.

3. Dengan Metode Analytical Hierarchy Process (AHP), penggunaan multikriteria dalam pemilihan lokasi menjadi lebih mudah. Jika alternatif lokasi memiliki nilai tinggi pada kriteria, maka termasuk lokasi yang tepat dan sebaliknya jika alternatif lokasi memiliki nilai kriteria yang kecil maka alternatif lokasi tersebut kurang tepat.

4. Metode Analytical Hierarchy Process (AHP) merupakan bagian dari Decision Support System (DSS), sehingga penggunaan metode ini dalam pemilihan lokasi dapat dijadikan sistem pendukung keputusan berbasis komputer interaktif yang dapat membantu pihak manajemen Dompet Dhuafa Yogyakarta.

\section{REFERENSI}

Laudon, Kenneth C., \& Laudon, Jane P. 2006. Management Information Systems: Managing The Digital Firm. Tenth Edition, Pearson Education International.

Saaty. 1990. Multicriteria Decision Making: The Analytic Hierarchy process-Planing Prioroty Setting. Resource Allocation. McGraww-Hill, New York

Thomas L. Saaty. 2010. Analytic Hierarchy Process. Prosiding: Jurnal. Vol. VI of the AHP Series, , 478 pp., RWS Publ., 2000 (revised). ISBN 0-9620317-6-3.

Zainal Arifin, 2010, Penerapan Metode Analytical Hierarchy Process (AHP) Untuk Menentukan Sisa Hasil Usaha Pada Koperasi Pegawai Negeri. Jurnal Informatika Mulawarman. Vol. 5, no 2. 
